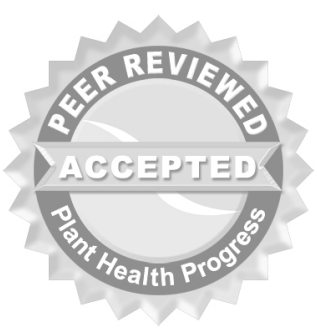

(C) 2010 Plant Management Network.

Accepted for publication 6 October 2009. Published 25 J anuary 2010.

\title{
Effect of Pre- and Post-Plant Fungicide and Fertilizer Treatments on Infection by Colletotrichum acutatum, Plant Survival, and Yield of Annual Strawberry in Florida
}

\author{
James C. Mertely, Teresa E. Seijo, and Natalia A. Peres, \\ University of Florida, Department of Plant Pathology, Gulf Coast \\ Research and Education Center, Wimauma, FL 33598
}

Corresponding author: Natalia A. Peres. nperes@ufl.edu

Mertely, J. C., Seijo, T. E., and Peres, N. A. 2010. Effect of pre- and post-plant fungicide and fertilizer treatments on infection by Colletotrichum acutatum, plant survival, and yield of annual strawberry in Florida. Online. Plant Health Progress doi: 10.1094/PHP-20100125-01-RS.

\begin{abstract}
The effects of pre-plant dips and post-plant treatments on the infection by Colletotrichum acutatum, survival, and yields of strawberry plants were evaluated over two seasons in Florida using naturally infected transplants imported from northern nurseries. Handling practices such as washing, refrigerating, and dipping plants in water had no effect on infection, survival, or yield. Pre-plant dips with the fungicide Switch 62.5 WDG (cyprodinil + fludioxonil) and, in some cases, with Abound 2.08F (azoxystrobin), reduced infection and plant mortality, and increased yield. Pre-plant dips with Oxidate (hydrogen peroxide) were ineffective and, in some cases, increased plant mortality and reduced yield. Fertilizer treatments, such as dipping and spraying plants with Brotomax (8-0-0 plus micronutrients) or application of slow-release Osmocote (15-9-12 plus micronutrients) after planting, had no effect or reduced plant survival and yield. Post-plant application of Surround WP, a kaolin clay intended to reduce heat stress and control mites and insects, had little or no effect on infection, survival, or yield. In summary, strawberry transplants infected with $C$. acutatum can be dipped in Switch or Abound at planting to reduce infection and increase survival and yield, but other treatments and practices examined are unlikely to have beneficial effects.
\end{abstract}

\section{I ntroduction}

Colletotrichum acutatum affects strawberry production worldwide by infecting virtually all plant parts and causing anthracnose fruit rot, lesions on petioles and stolons, crown infections, and roots rots $(3,11)$. Anthracnose fruit rot is the most common problem, but transplants infected by C. acutatum establish slowly and suffer excessive mortality due to the development of root and crown infections. Affected plants fail to develop an adequate root system for several weeks after transplanting. Old structural roots become brown to black and develop few new fibrous roots. New peg roots develop brown lesions, die back from the tip, or fail to emerge from the crown (9). In severe cases, C. acutatum enters the crown causing a basal crown rot. When overhead irrigation is withdrawn after the establishment period, most plants that develop crown rot eventually die. Surviving plants are stunted or variable in size, flower late, and produce a poor early crop. Cultivars that are highly susceptible to anthracnose fruit rot, e.g., Camarosa and Treasure, are also susceptible to root necrosis and poor establishment (9).

In Israel and California, C. acutatum survives between crops in the soil, and on volunteer plants and plant debris $(2,4)$. In Florida, the related fungus $\mathrm{C}$. gloeosporioides fails to survive the hot, wet summers (14) followed by soil fumigation with methyl bromide in the fall. Infected transplants are believed to be the primary source of C. acutatum in Florida (9). The use of disease-free plants could reduce disease incidence greatly. For example, the occurrence of crown rots caused by C. gloeosporiodes and C. fragariae has been reduced by the production of disease-free transplants in northern nurseries $(5,7)$. However, 
problems with C. acutatum persist because the pathogen is adapted to cooler areas.

C. acutatum frequently colonizes leaves and petioles of runner plants in the nursery. Symptoms may not be visible in the nursery environment and this pathogen can reproduce by secondary conidiation on symptomless plants (6). If inoculum is allowed to build up and the weather is favorable, flowers and fruit are attacked and lesions develop on the petioles and stolons. In addition, healthy plants may be contaminated with inoculum during normal digging, trimming, and packing operations in the nursery. Eastburn and Gubler (2) showed that washing plants with running water eliminated the inoculum and decreased disease incidence substantially. Once transplanted, disease spread below ground is unlikely since the root systems are relatively isolated; however, above-ground spread on the foliage occurs and may be facilitated by overhead irrigation during establishment. Observations in Florida (J. C Mertely and N. A. Peres, unpublished) suggest that disease severity may be influenced by the degree of plant stress during establishment. Measures that reduce plant stress may also reduce the severity of root necrosis disease. Preliminary studies suggested that plant losses are increased by high levels of fertilization (J. C Mertely and N. A. Peres, unpublished). High nitrogen levels increase disease severity with crown rot caused by C. gloeosporioides and C. fragariae (13), but little is known about the effects of nitrogen fertilization on survival of transplants infected by C. acutatum.

The objective of this study was to determine the effects of pre-plant dips of fungicides or fertilizers and post-plant treatments on infection by C. acutatum, plant survival, and yield of annual strawberries in Florida.

\section{Pre- and Post-plant Evaluations of Products}

General methods. Replicated field experiments were conducted during the 2003-2004 and 2004-2005 growing seasons to test the ability of pre-and postplant treatments to reduce mortality and increase yields of strawberry transplants naturally infected by C. acutatum. Experiments were conducted at the Gulf Coast Research and Education Center of the University of Florida in Dover, FL. In October of 2003 and 2004, green-top, bare-root runner plants from northern nurseries were selected for uniformity, and planted in plasticmulched raised beds. Both sets of transplants contained some plants with petiole lesions characteristic of infection by C. acutatum. Treatments were applied by immersing (dipping) plants in solutions or suspensions of test products in water prior to planting (pre-plant treatments) or by treating plants after establishment (post-plant treatments).

Treatments. Ten treatments were tested in the 2003-2004 season (Table 1). Four treatments involved dipping plants for $5 \mathrm{~min}$ in water containing Abound 2.08F (22.9 \% azoxystrobin, Syngenta, Greensboro, NC), Brotomax (8-0-o plus micronutrients, Helena Chemical Co., Collierville, TN), Oxidate $\left(27 \% \mathrm{H}_{2} \mathrm{O}_{2}\right.$, Biosafe Systems LLC, East Hartford, CT), or Switch 62.5WDG (cyprodinil + fludioxonil, Syngenta, Greensboro, NC) at the rates indicated. Brotomax was also applied as a foliar spray (0.5\% in 100 gal/acre) on 7 November 2003, 16 December 2003, and 2 February 2004 to plants treated pre-plant with the same product. Plants dipped in water for 5 min served as an appropriate control (wet control). Two water treatments were evaluated to test the effects of washing plants thoroughly with a garden hose to remove adhering soil particles followed by a 5 -min soak in water just before planting; or washing with a hose the day before, storing at $38^{\circ} \mathrm{F}$ overnight, soaking in water for $5 \mathrm{~min}$, and then planting. Post-plant treatments included the application of Surround WP (95\% kaolin clay, Tessenderlo Kerley Inc., Phoenix, AZ), a product that reduces heat stress and mite and insect infestations, or Osmocote Plus (Scotts Company LLC, Maryville, $\mathrm{OH}$ ), a slow release 15-9-12 fertilizer with micronutrients. Surround WP was sprayed on plots at $37.5 \mathrm{lb} / 100$ gal on 24 October, one day after overhead irrigation for plant establishment was terminated; Osmocote was applied to the soil surface around each plant at $0.2 \mathrm{oz} /$ plant on 22 October and 17 December 2003, in addition to the standard commercial fertigation program 
used on all plants in this study, to test the effects of high fertility. As a control for these treatments, nonwashed, nontreated plants were set into the beds according to normal commercial practice (dry control).

Table 1. Effect of pre- and post plant treatments on the colonization of petioles by Colletotrichum acutatum, mortality, and yield of strawberries in the 2003-2004 season.

\begin{tabular}{|c|c|c|c|c|c|c|c|}
\hline \multicolumn{2}{|c|}{\begin{tabular}{|l|} 
Treatment \\
\end{tabular}} & \multirow{2}{*}{ 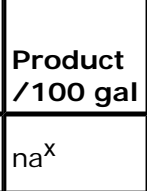 } & \multirow{2}{*}{\begin{tabular}{|l}
$\begin{array}{l}\text { Petiole } \\
\text { colonization } \\
(\%)^{\mathrm{V}}\end{array}$ \\
$81.7 \mathrm{a}^{\mathrm{y}}$
\end{tabular}} & \multirow{2}{*}{\begin{tabular}{|l|}
$\begin{array}{l}\text { Plant } \\
\text { mortality } \\
(\%)^{\mathrm{w}}\end{array}$ \\
$1.7 \mathrm{c}$
\end{tabular}} & \multirow{2}{*}{\begin{tabular}{|l}
$\begin{array}{l}\text { Early } \\
\text { yield } \\
\text { (lb/acre) }\end{array}$ \\
$5,500 \mathrm{ab}$
\end{tabular}} & \multirow{2}{*}{\begin{tabular}{|l} 
Late yield \\
(lb/acre)
\end{tabular}} & \multirow{2}{*}{\begin{tabular}{|l}
$\begin{array}{l}\text { Total yield } \\
\text { (lb/acre) }\end{array}$ \\
30,000 abco
\end{tabular}} \\
\hline $\begin{array}{l}\text { Pre- } \\
\text { plant }\end{array}$ & $\begin{array}{l}\text { Wet control } \\
\text { (5-min dip in water) }\end{array}$ & & & & & & \\
\hline & Water (wash, 5-min dip) & na & $61.7 \mathrm{abc}$ & $2.5 \mathrm{bc}$ & $5,200 \mathrm{bc}$ & $25,900 a b c$ & $31,100 \mathrm{abc}$ \\
\hline & $\begin{array}{l}\text { Water (wash day before, } \\
\text { store at } 38^{\circ} \mathrm{F}, 5 \text {-min dip) }\end{array}$ & na & ND & $5.0 \mathrm{bc}$ & $5,000 \mathrm{bc}$ & $24,200 \mathrm{bc}$ & $29,200 \mathrm{bcd}$ \\
\hline & $\begin{array}{l}\text { Brotomax (5-min dip 1\%, } 3 \\
\text { foliar appl. } 0.5 \% \text { ) }\end{array}$ & $\begin{array}{l}1.0 \mathrm{gal}, \\
0.5 \mathrm{gal}\end{array}$ & $50.0 \mathrm{bc}$ & $3.3 \mathrm{bc}$ & $4,100 \mathrm{~cd}$ & $23,700 \mathrm{bc}$ & $27,800 \mathrm{~cd}$ \\
\hline & $\begin{array}{l}\text { Oxidate } \mathbf{2 7 \%} \quad \mathbf{H}_{\mathbf{2}} \mathbf{O}_{\mathbf{2}} \\
\text { (5-min dip) }\end{array}$ & $1 \mathrm{gal}$ & $66.7 \mathrm{abc}$ & $6.7 \mathrm{~b}$ & $3,800 \mathrm{~d}$ & $24,100 \mathrm{bc}$ & $27,800 \mathrm{~cd}$ \\
\hline & $\begin{array}{l}\text { Abound 2.08F } \\
\text { ( } 5 \text {-min dip) }\end{array}$ & $8.0 \mathrm{fl} \mathrm{oz}$ & $45.0 \mathrm{c}$ & $1.7 \mathrm{C}$ & $4,900 \mathrm{bc}$ & $27,000 \mathrm{ab}$ & $32,000 \mathrm{a}$ \\
\hline & $\begin{array}{l}\text { Switch 62.5WDG } \\
\text { (5-min dip) }\end{array}$ & $6.5 \mathrm{oz}$ & $0.0 \mathrm{~d}$ & $1.7 \mathrm{c}$ & $4,700 \mathrm{bcd}$ & $28,600 \mathrm{a}$ & $33,300 \mathrm{a}$ \\
\hline \multirow[t]{3}{*}{$\begin{array}{l}\text { Post- } \\
\text { plant }\end{array}$} & $\begin{array}{l}\text { Dry control } \\
\text { (no wash, no dip) }\end{array}$ & na & $75.0 \mathrm{ab}$ & $1.7 \mathrm{C}$ & $5,500 a b$ & $25,200 a b c$ & $30,700 \mathrm{abc}$ \\
\hline & $\begin{array}{l}\text { Surround WP } \\
\text { (no wash, no dip) }\end{array}$ & $37.5 \mathrm{lb}$ & $N D^{Z}$ & $2.5 \mathrm{bc}$ & $6,600 \mathrm{a}$ & $27,300 \mathrm{ab}$ & $33,800 \mathrm{a}$ \\
\hline & $\begin{array}{l}\text { Osmocote Plus 15-9-12 } \\
\text { (no wash, no dip) }\end{array}$ & na & ND & $12.5 \mathrm{a}$ & $4,100 \mathrm{~cd}$ & $22,700 \mathrm{c}$ & $26,800 \mathrm{~d}$ \\
\hline
\end{tabular}

$\checkmark$ Percent petioles colonized by C. acutatum on 24 Oct 2003 ( 7 days after planting); only pre-plant treatments which could have affected petiole colonization and controls were evaluated.

w Percent dead, dying, and severely stunted plants 5 weeks after planting.

$x_{\text {na }}=$ not applicable.

y Figures in a column followed by the same letter are not significantly different by Fisher's protected LSD test $(P<0.05)$.

${ }^{\mathrm{z}} \mathrm{ND}=$ Not Determined .

The experiment was repeated with minor modifications in the 2004-2005 season (Table 2). Brotomax was not retested and a lower rate of Abound (6.5 fl $\mathrm{oz} / 100$ gal water) was used for the dip treatment. Surround WP was applied in two coats at $25 \mathrm{lb} / 100$ gal each on 28 October 2004 and Osmocote Plus was applied as previously described on 26 October and 15 December 2004. 
Table 2. Effect of pre- and post plant treatments on petiole colonization and isolation frequency from crowns of Colletotrichum acutatum, plant mortality, and yield of strawberries in the 2004-2005 season.

\begin{tabular}{|c|c|c|c|c|c|c|c|c|}
\hline \multicolumn{2}{|c|}{ Treatment } & \multirow{2}{*}{\begin{tabular}{|l|} 
Product \\
/ 100 gal \\
$n a^{y}$ \\
\end{tabular}} & \multirow{2}{*}{\begin{tabular}{|l|}
$\begin{array}{l}\text { Petiole } \\
\text { colonization } \\
(\%)^{v}\end{array}$ \\
$98 \mathrm{ab}^{\mathrm{z}}$ \\
\end{tabular}} & \multirow{2}{*}{\begin{tabular}{|l|}
$\begin{array}{l}\text { Plant } \\
\text { mortality } \\
(\%)^{\mathrm{W}}\end{array}$ \\
$25.0 \mathrm{~b}$ \\
\end{tabular}} & \multirow{2}{*}{\begin{tabular}{|l|}
$\begin{array}{l}\text { I solation } \\
\text { frequency } \\
(\%)^{\mathrm{x}}\end{array}$ \\
$33.3 \mathrm{ab}$ \\
\end{tabular}} & \multirow{2}{*}{ 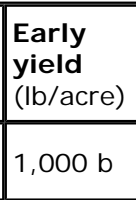 } & \multirow{2}{*}{ 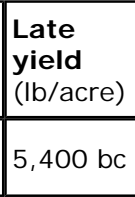 } & \multirow{2}{*}{\begin{tabular}{|l}
$\begin{array}{l}\text { Total } \\
\text { yield } \\
\text { (lb/acre) }\end{array}$ \\
$6,300 \mathrm{bc}$
\end{tabular}} \\
\hline $\begin{array}{l}\text { Pre- } \\
\text { plant }\end{array}$ & $\begin{array}{l}\text { Wet control (5-min } \\
\text { dip in water) }\end{array}$ & & & & & & & \\
\hline & $\begin{array}{l}\text { Water } \\
\text { (wash, 5-min dip) }\end{array}$ & na & $93 a b$ & $34.2 \mathrm{ab}$ & $39.3 a b$ & $600 \mathrm{~b}$ & $2,900 \mathrm{c}$ & $3,500 \mathrm{c}$ \\
\hline & $\begin{array}{l}\text { Water (wash day } \\
\text { before, store at } \\
38^{\circ} \mathrm{F}, 5 \text {-min dip) }\end{array}$ & na & $93 a b$ & $25.8 \mathrm{~b}$ & $26.3 \mathrm{~b}$ & $900 \mathrm{~b}$ & $5,700 \mathrm{bc}$ & $6,600 \mathrm{bc}$ \\
\hline & $\begin{array}{l}\text { Oxidate 27\% } \\
\text { (5-min dip) }\end{array}$ & $64 \mathrm{fl} \mathrm{oz}$ & $100 \mathrm{a}$ & 44.2 a & $48.1 \mathrm{ab}$ & $500 \mathrm{~b}$ & $2,800 \mathrm{c}$ & $3,300 \mathrm{c}$ \\
\hline & $\begin{array}{l}\text { Abound 2.08F } \\
\text { (5-min dip) }\end{array}$ & $6.5 \mathrm{fl} \mathrm{oz}$ & $90 \mathrm{~b}$ & $5.8 \mathrm{c}$ & $51.7 \mathrm{a}$ & $1,700 \mathrm{a}$ & $7,500 \mathrm{~b}$ & $9,200 \mathrm{~b}$ \\
\hline & $\begin{array}{l}\text { Switch 62.5WDG } \\
\text { (5-min dip) }\end{array}$ & $6.5 \mathrm{oz}$ & $35 \mathrm{c}$ & $6.7 \mathrm{c}$ & $8.9 \mathrm{c}$ & $2,300 \mathrm{a}$ & $16,200 \mathrm{a}$ & $18,500 \mathrm{a}$ \\
\hline \multirow[t]{3}{*}{$\begin{array}{l}\text { Post- } \\
\text { plant }\end{array}$} & \begin{tabular}{|l} 
Dry control \\
(no wash, no dip)
\end{tabular} & na & $95 a b$ & $39.2 \mathrm{ab}$ & $38.6 \mathrm{ab}$ & $600 \mathrm{~b}$ & $3300 \mathrm{c}$ & $3,900 \mathrm{c}$ \\
\hline & $\begin{array}{l}\text { Surround WP } \\
\text { (no wash, no dip) }\end{array}$ & $25.0 \mathrm{lb}$ & $98 a b$ & $37.5 a b$ & $42.5 \mathrm{ab}$ & $700 \mathrm{~b}$ & $4000 \mathrm{c}$ & $4,700 \mathrm{c}$ \\
\hline & $\begin{array}{l}\text { Osmocote Plus 15-9- } \\
12 \text { (no wash, no dip) }\end{array}$ & na & $100 \mathrm{a}$ & $40.8 a b$ & 55.9 a & $300 \mathrm{~b}$ & $3,200 \mathrm{c}$ & $3,500 \mathrm{c}$ \\
\hline
\end{tabular}

$\checkmark$ Percent petioles colonized by C. acutatum on 28 Oct 2004 ( 9 days after planting).

w Percent dead and dying plants 5 weeks after planting.

$x$ Percent living plants from which $C$. acutatum was isolated from the crown 7 weeks after planting.

$\mathrm{y}$ na $=$ not applicable.

${ }^{z}$ Figures in a column followed by the same letter are not significantly different by Fisher's protected LSD test $(P<0.05)$.

Similar protocols and cultural practices were followed each season. The experiments were arranged in a randomized complete block design with four blocks, each consisting of a single bed. Beds were 28 inches wide on 4 -ft centers. Individual plots consisted of 30 plants in two staggered rows per bed. Plants were spaced 15 inches apart within rows and 12 inches apart between rows. Plots were separated by a $5 \mathrm{ft}$-long, nonplanted gap within a bed, and by a nonplanted bed between each experimental bed. The 2003-2004 experiment was conducted with the moderately susceptible cultivar Strawberry Festival, whereas the highly susceptible cultivar Treasure was used in 2004-2005. The transplants were set into methyl-bromide:chloropicrin (98:2) fumigated soil in plastic-mulched raised beds on 17 October 2003 and 19 October 2004 and irrigated by overhead sprinklers for 6 days in 2003 or 8 days in 2004 to facilitate establishment, then irrigated and fertilized through drip tape according to standard Florida commercial practices for the remainder of the experiment. To suppress plot-to-plot spread of C. acutatum, plants were sprayed weekly with captan, similarly to a commercial field, using a tractormounted hydraulic sprayer at 100 gal/acre. In 2003-2004, Captan 80WP was applied at $2.5 \mathrm{lb} /$ acre from November through January and at $3.75 \mathrm{lb} /$ acre in February and early March. Elevate 50WDG (fenhexamid) at $1 \mathrm{lb} /$ acre was tanked mixed with captan and applied on 6 and 13 February to suppress Botrytis fruit rot. In 2004-2005, Captan 8oWP was applied at $1.88 \mathrm{lb} /$ acre in November through January, and $2.8 \mathrm{lb} /$ acre in February and March. Since the plants used in these experiments were already infected, topical applications of these fungicides should not affect existing infections, but should control any plot-to-plot disease spread.

Evaluations. In 2003-2004, plant colonization by C. acutatum was evaluated 7 days after planting using a petiole test developed by Mertely and Legard (10). One old leaf was removed from plants 16 through 30 in plots of selected treatments. Petioles were detached and trimmed to 2.5 to 3.0 inches, frozen at $-20^{\circ} \mathrm{F}$ for $2 \mathrm{~h}$, surface disinfested in $0.05 \%$ sodium hypochlorite for 
2 min, and incubated on moist filter paper at room temperature under constant fluorescent light. After 6 days, the petioles were examined for characteristic acervuli of Colletotrichum spp. and the percentage of colonized petioles was recorded. In 2004-2005, petiole colonization in all treatments was evaluated 9 days after planting using petioles from plants 16 to 25 in each plot. Detached petioles were handled as in 2003-2004. In both years, acervuli bearing conidia were observed periodically under a compound microscope to confirm that the fungus being evaluated was C. acutatum.

In both seasons, the number of dead and dying plants in each 30-plant plot was recorded and expressed as a percentage 5 weeks after transplanting. In 2003-2004, plants 16 to 30 in each plot were removed 7 weeks after planting to obtain dry weights of the crowns and foliage (data not shown). In 2004-2005, plants 16 to 30 were removed 7 weeks after planting to make isolations from diseased crowns. Sacrificed plants were washed and the crowns were split longitudinally. Isolations were made from each crown showing internal discoloration by making successive cuts with a flamed scalpel and transferring two pieces of diseased tissue to a semi-selective medium for Colletotrichum consisting of the following per liter: potato dextrose agar (PDA) (39 g), streptomycin (0.1 g), ampicillin (0.25 g), and $4 \mathrm{mg}$ of iprodione (Rovral $50 \mathrm{WP}$ dissolved in $80 \%$ ethanol at $4 \mathrm{~g} /$ liter). The antibiotics and iprodione were added to autoclaved PDA just prior to pouring. Isolation plates were incubated at $75^{\circ} \mathrm{F}$ for 5 to 7 days. Confirmation of C. acutatum in the isolation plates was done microscopically by conidial morphology.

Yields were obtained throughout the season by harvesting plots twice weekly from 16 December 2003 to 26 March 2004 in the first season and from 14 December 2004 to 25 March 2005 in the second (30 harvests each season). Healthy fruit weighing more than one-third oz were weighed to obtain marketable yield. Yields were expressed in lb/acre for early, late, and whole season production periods. Early season in 2003-2004 was from 14 December 2003 to 31 January 2004, late season from 1 February to 26 March, and whole season was the total of the two. In 2004-2005, early season was from 14 December 2004 to 31 January 2005, late season from 1 February 2005 to 25 March 2005, and whole season was the total of the two. Marketable fruit were weighed and yield expressed in $\mathrm{lb} / \mathrm{acre}$.

A two-way ANOVA was performed on each data set using SAS. Treatment means were separated by Fisher's protected LSD procedure $(\mathrm{P} \leq 0.05)$. Petiole colonization and isolation frequency percentage data were transformed to arcsine square roots prior to analysis. The nontransformed means are reported.

\section{Pre- and Post-plant Treatment Effects}

2003-2004. In most treatments, half or more of the petioles tested were colonized by C. acutatum 7 days after planting (Table 1). Only pre-plant treatments which could have affected petiole colonization and controls were evaluated. The frequency of colonization was not affected by pre-plant washing of the transplants compared to the dry control. Pre-plant dips in Abound, Brotomax, and Switch all reduced petiole colonization, but Switch was significantly more effective than Abound or Brotomax. Despite the high colonization rates, plant mortalities were relatively low 5 weeks after transplanting. The dry control did not differ in plant mortality from the wet control nor from plants that were washed or washed and refrigerated. Postplant applications of Osmocote significantly increased mortality compared to the dry control. Mortality in most of the pre-plant treatments did not differ from that in the wet or dry control, but was higher in the Oxidate treatment. Marketable yields often reflected treatment effects on plant mortality. The Osmocote treatment had lower early-season and total yield than the dry control. The Oxidate and the Brotomax treatments had significantly lower early yields than the corresponding wet control, but late-season and total yield were unaffected. Dipping in Switch increased late season yield, but not early or total season yields. No other treatment significantly improved early-season, lateseason, or total yield compared to the appropriate controls 
2004-2005. Petiole colonization was higher in 2004-2005 than in the previous season (Table 2). Colonization rates exceeded $90 \%$ in all of the treatments, except the pre-plant application of Switch, where colonization was reduced to $35 \%$. Plant mortality was high in 2004-2005 compared to 20032004, possibly due to the poor condition of the transplants in the shipment used. There were no differences in mortality among the post-plant treatments. Of the pre-plant treatments, Abound and Switch significantly reduced mortality compared to the wet control. Mortality was higher in the Oxidate treatment. C. acutatum was isolated frequently from plant crowns 7 weeks after planting. There were no differences in isolation frequency among the post-plant treatments. Of the pre-plant treatments, only Switch significantly reduced the frequency of isolation compared to the wet control and the water treatments. In 2004-2005, yields were generally low due to high plant mortality, and strongly reflected the differences in mortality among the various treatments. None of the post-plant treatments significantly affected early, late, or total yield. Of the preplant treatments, Switch and Abound increased early yield. Switch also significantly increased late and total yield compared to any of other treatments. Despite the fact that the late and total yield for the Abound treatment did not differ from the wet control, it increased yields compared to the dry control.

\section{Recommendations for Pre- and Post-plant Treatments}

None of the handling practices tested appreciably affected the infection of plants by C. acutatum, mortality, or yield of annual strawberry in Florida. In contrast to the results of Eastburn and Gubler (2), washing of plants in running water to remove soil did not affect infection, mortality, or yield in our study. Refrigeration of the plants overnight after washing and prior to planting likewise had no significant effects. Thus, it appears that growers can employ any of these practices without affecting plant survival or production.

The post-plant treatments we evaluated were largely ineffective in reducing plant mortality and increasing marketable yield. Previous research on crown rot caused by C. gloeosporioides (13) and our observations in Florida have shown that high levels of nitrogen appear to increase susceptibility to disease and reduce plant survival. In Florida, the common practice of incorporating small quantities of nitrogen fertilizers in the soil prior to planting did not increase strawberry yields (12). In this study, dip and foliar applications of fertilizer, and applications of slow-release fertilizers after planting did not increase survival or yield, and, in some cases, were detrimental. Thus, fertigation of strawberry plants through drip tubing appears to provide sufficient nutrients to supply crop needs; supplemental pre-plant or post-plant applications are not be beneficial and may increase susceptibility to diseases caused by Colletotrichum spp. Application of Surround, a kaolin clay product, reduces heat stress after transplant, but Surround failed to significantly increase plant survival or yield.

Of the pre-plant treatments, only a 5-min dip in Switch or Abound provided significant benefits. Daugovich, et al. (1) found that pre-plant dips in Switch, Quadris (azoxystrobin), and Pristine (pyraclostrobin + boscalid) reduced disease incidence and increased plant size and marketable yields in tests using plants inoculated with C. acutatum in California. Thus, similar results now have been demonstrated with both inoculated and naturally infected plants. Preplant dips with Oxidate had no beneficial effects and produced among the highest plant mortalities in both tests. Since the active ingredient in Oxidate is the surface disinfestant, hydrogen peroxide, it is not surprising that this product did not reduce existing infections. Treatment with Oxidate may have weakened the plants and increased plant mortality from the pathogen. Therefore, if growers receive shipments of transplants which are suspected to be infected with C. acutatum, plants can be dipped in Switch or Abound to increase plant survival and yield. Dip treatment with these products may also reduce the amount of inoculum available to initiate outbreaks of anthracnose fruit rot later in the season (8). Although Switch, Abound, and Oxidate are registered for preplant dips (9), only Switch and Abound/Quadris appear to be effective for that purpose based on our findings and those of Daugovich, et al. (1). 


\section{Literature Cited}

1. Daugovich, O., Su, H., and Gubler, W. D. 2009. Preplant fungicide dips of strawberry transplants to control anthracnose caused by Colletotrichum acutatum in California. HortTechnology 19:317-323.

2. Eastburn, D. M., and Gubler, W. D. 1990. Strawberry anthracnose: Detection and survival of Colletotrichum acutatum in soil. Plant Dis. 74:161-163.

3. Freeman, S., and Katan, J. 1997. Identification of Colletotrichum species responsible for anthracnose and root necrosis of strawberry in Israel. Phytopathology 87:516521.

4. Freeman, S., Shalev, Z., and Katan, J. 2002. Survival of Colletotrichum acutatum and C. gloeosporioides pathogenic on strawberry. Plant Dis. 86:965-970.

5. Howard, C. M., Maas, J. L., Chandler, C. K., and Albreght, E. E. 1992. Anthracnose of strawberry caused by the Colletotrichum complex in Florida. Plant Dis. 76:976981.

6. Leandro, L. F. S., Gleason, M. L., Nutter, F. W. Jr., Wegulo, S. N., and Dixon, P. M. 2001. Germination and sporulation of Colletotrichum acutatum on symptomless strawberry leaves. Phytopathology 91:659-664.

7. McInnes, T. B., Black, L. B., and Gatti, J. M. 1992. Disease-free plants for management of strawberry crown rot. Plant Dis. 76:260-264.

8. Mertely, J. C., and Peres, N. A. 2004. To dip or not to dip. Sept. 3-4, Berry/Vegetable Times. Gulf Coast Res. and Ed. Center, Univ. of Florida-IFAS, Wimauma, FL.

9. Mertely, J. C., and Peres, N. A. 2008. Root necrosis of strawberries caused by Colletotrichum acutatum. Online. Electronic Data Info. Source PP211. Univ. of Florida-IFAS, Gainesville, FL.

10. Mertely, J. C., and Legard, D. E. 2004. Detection, isolation, and pathogenicity of Colletotrichum spp. from strawberry petioles. Plant Dis. 88:407-412.

11. Peres, N. A., Timmer, L. W., Adaskaveg, J. E., and Correll, J. C. 2005. Life styles of Colletotrichum acutatum. Plant Dis. 89:784-796.

12. Santos, B. M., and Whidden, A. J. 2008. Nitrogen fertilization of strawberry cultivars: Is preplant starter fertilizer needed? Online. Electronic Data Info. Source HS1116. Univ. of Florida-IFAS, Gainesville, FL.

13. Smith, B. J. 2009. Nitrogen fertilizer affects the severity of anthracnose crown rot disease of greenhouse grown strawberries. Online. Plant Health Progress doi:10.1094/PHP-2009-0609-01-RS.

14. Ureña-Padilla, A. R., Mitchell, D. J., and Legard, D. E. 2001. Oversummer survival of inoculum of Colletotrichum crown rot in buried strawberry crown tissue. Plant Dis. 85:750-754. 